\title{
Study on the Concentration of Acrylic Acid and Acetic Acid by Reverse Osmosis
}

\author{
Qian Liu ${ }^{1,2}$, Lixin Xie ${ }^{1,2, *}$, Hanxiao Du ${ }^{1,2}$, Shichang $X u^{1,2}$ and Yawei Du ${ }^{3, *}$ \\ 1 School of Chemical Engineering and Technology, Tianjin University, Tianjin 300072, China; \\ 1q202071@126.com (Q.L.); d826258049@126.com (H.D.); xushichang@sina.com (S.X.) \\ 2 Tianjin Key Laboratory of Membrane Science and Desalination Technology, State Key Laboratory of \\ Chemical Engineering (Tianjin University), Tianjin 300072, China \\ 3 School of Chemical Engineering and Technology, Hebei University of Technology, Tianjin 300130, China \\ * Correspondence: xie_lixin@tju.edu.cn (L.X.); sonicduyawei001@126.com (Y.D.)
}

Received: 6 June 2020; Accepted: 4 July 2020; Published: 6 July 2020

\begin{abstract}
In the production of acrylic acid, the concentration of acrylic acid solution from the adsorption tower was low, which would lead to significant energy consumption in the distillation process to purify acrylic acid, along with the production of a large amount of wastewater. Reverse osmosis (RO) was proposed to concentrate the acrylic acid aqueous solution taken from a specific tray in the absorption tower. The effects of operating conditions on the permeate flux and acid retention were studied with two commercial RO membranes (SWC5 and SWC6). When the operating pressure was $4 \mathrm{MPa}$ and the temperature was $25^{\circ} \mathrm{C}$, the permeate fluxes of two membranes were about $20 \mathrm{~L} \cdot \mathrm{m}^{-2} \cdot \mathrm{h}^{-1}$. The acrylic acid and acetic acid retentions were about $80 \%$ and $78 \%$, respectively. After being immersed in the acid solutions for several months, the characteristics of the two membranes were tested to evaluate their acid resistance. After six months of exposure to the acid solution containing $2.5 \%$ acrylic acid and $2.5 \%$ acetic acid, the retentions of acrylic acid and acetic acid were decreased by $5.7 \%$ and $4.1 \%$ for SWC 5 and $4.9 \%$ and $2.2 \%$ for SWC 6 , respectively. The changes of membrane surface morphology and chemical composition showed the hydrolysis of some amide bonds.
\end{abstract}

Keywords: reverse osmosis (RO); concentration; acrylic acid; acetic acid; membrane stability

\section{Introduction}

Acrylic acid (AA) is a versatile monomer which is widely used in the synthesis of plastics, synthetic rubbers, superabsorbent polymers, coatings, detergents, fibers, and specialty resins [1-5]. Currently, the main production technology of acrylic acid is the two-step gas-phase oxidation of propylene [1-3]. The mixed gases produced in the oxidation process are introduced into the bottom of the absorption tower. Acrylic acid and multiple by-products, including acetic acid (HAc), formic acid, maleic acid, acrolein, acetaldehyde acetone, etc. [6], are absorbed by the water sprayed down from the top of absorption tower. Then, the acrylic acid aqueous solution can be obtained at the bottom. Limited by the high concentration of water vapor at the inlet of the oxidation reactor and the absorption method, the concentration of acrylic acid in the bottom of the absorption tower is relatively low, which results in a large amount of energy consumption and wastewater production in downstream distillation process [7]. Some methods were proposed to improve the concentration of the acrylic acid solution before the distillation process. Briegel et al. [8] used a condenser tower equipped with multiple external heat exchangers instead of the conventional absorption tower to indirectly cool and recover a higher concentration of (meth)acrylic acid solution from the gaseous steam. Min et al. [9] used the extraction solvent to extract (meth)acrylic acid from the side stream of the absorption tower. Although the 
concentration of (meth)acrylic acid solution entering the distillation tower was increased, the large amount of extraction solvent was inevitable.

In recent years, membrane technologies, including microfiltration (MF), ultrafiltration (UF), nanofiltration (NF), and reverse osmosis (RO), have attracted great attention during the industrial production process [10-13]. With the development of a variety of high-performance $\mathrm{RO}$ membranes, such as antifouling membranes, acid resistance membranes, ultra-low pressure membranes, and high retention membranes, the application of $\mathrm{RO}$ has gradually expanded from seawater desalination to the fields of wastewater treatment [14], food processing [15], petrochemical industry [16], pharmaceutical industry [17], and acid concentration and separation [14,18]. Ricci et al. [19] integrated NF and RO to separate noble metals ions and concentrate sulfuric acid from the gold mining effluent. The rejection of metals ions by the NF membrane was above $90 \%$, and the sulfuric acid could permeate through the membrane. With the recovery of $50 \%$, an increase of $99 \%$ in sulfuric acid concentration compared to the feed was achieved. González et al. [18] determined the feasibility of purifying industrial phosphoric acid solution by RO. Moreover, the retention of cationic impurities were $99.3 \%$, and $46.3 \%$ of acid permeation were achieved. Zhou et al. [20] separated acetic acid from model lignocellulosic hydrolysates by RO. It was shown that the separation factor of acetic acid over sugars was above 200 . Chen et al. [21] developed an ethanol promotion method to facilitate the removal of furfural and acetic acid from hydrolysate. When the ratio of ethanol/acetic acid concentration was 5.80, the acetic acid retention of PA2-4040 RO membrane was only 10\%. Ahsan [22] reported that multi-stage RO could recover about 70\% acetic acid from prehydrolysis liquor of kraft. Tan et al. [23] immersed the SWC5 and SWC6 membranes in the hydrochloric acid solution with a pH value of 1 for $2 \mathrm{~h}$. Although the hydrolysis of some amide bonds of the treated membranes was observed, the salt retention of the two membranes were decreased by less than $1 \%$. These studies indicated that the RO had great potential in the concentration and separation of acid. However, the above studies did not assess the long-term stability of the membrane in the specific acid solution.

In this study, RO was proposed to concentrate the acrylic acid aqueous solution taken from a specific tray in the absorption tower. The concentrated acrylic acid solution was returned to the absorption tower for continuous absorption. The permeate from $\mathrm{RO}$ was reused as absorbent. The utilization of the process would decrease the amount of fresh absorbent and increase the concentration of acrylic acid in the bottom of the absorption tower, thereby decreasing the amount of wastewater production and energy consumption in the distillation process.

The feasibility of using $\mathrm{RO}$ to concentrate the synthetic solution containing acrylic acid and acetic acid was evaluated in this paper. The effects of operating pressure, temperature and feed concentration on permeate flux and acid retention were investigated. The stability of RO membrane was also tested by detecting the membrane characteristics after continuous exposure to the acid solution.

\section{Materials and Methods}

\subsection{Materials}

Two commercial seawater RO membranes (SWC5 and SWC6) were acquired from Hydranautics, Oceanside, CA, USA, which were marked as C5 and C6 in this study, respectively. Table 1 showed the specifications of the two membranes. 
Table 1. The specifications of the two RO membranes used in this study.

\begin{tabular}{ccc}
\hline Membranes & C5 & C6 \\
\hline Active layer & polyamide $(\mathrm{PA})$ & PA \\
Operating $\mathrm{pH}$ & $2-11$ & $2-11$ \\
Maximum operating temperature $\left({ }^{\circ} \mathrm{C}\right)$ & 45 & 45 \\
Maximum operating pressure $(\mathrm{MPa})$ & 8.27 & 8.27 \\
$\mathrm{NaCl}$ retention $(\%)$ & $99.8^{\mathrm{a}}$ & $99.8^{\mathrm{a}}$ \\
Permeate flow rate $\left(\mathrm{m}^{3} / \mathrm{d}\right)$ & $34.1^{\mathrm{a}}$ & $45.4^{\mathrm{a}}$
\end{tabular}

a The test conditions specified by the manufacturer were: $32 \mathrm{~g} \cdot \mathrm{L}^{-1} \mathrm{NaCl}$ solution at $5.52 \mathrm{MPa}, 10 \%$ recovery, $25^{\circ} \mathrm{C}$ and $\mathrm{pH}$ 6.5-7.0. The effective membrane area was $37.2 \mathrm{~m}^{2}$.

Acetic acid ( $\geq 99.5 \%)$ was purchased from Tianjin Kemel Co., Ltd., Tianjin, China. Acrylic acid $(\geq 99.5 \%)$ and sodium chloride $(\geq 99.5 \%)$ were purchased from Tianjin Damao Co., Ltd., Tianjin, China. Anhydrous grade ethanol was obtained from Aladdin Reagent Co., Ltd., Shanghai, China.

\subsection{Filtration Experiment}

All filtration experiments were carried out by a lab-made cross-flow RO filtration apparatus, as illustrated in Figure 1. The apparatus mainly consisted of feed tank, heat exchanger, high-pressure pump, membrane cells, pressure gauges, and rotameter. The effective area of the membrane cell was $31.16 \mathrm{~cm}^{2}$.

The permeate flux and acid retention of the $\mathrm{RO}$ membranes were tested under different operating conditions (pressure, temperature, and feed concentration). The operating pressure was adjusted by the valve on the outlet of the concentrate. The heat exchanger was used to control the solution temperature. The system was operated under a recirculating flow rate of $1.5 \mathrm{~L} \cdot \mathrm{min}^{-1}$. The permeate flux was obtained by measuring the volume of permeate over a period of time, and the acid retention was determined through analyzing the acid concentrations of permeate and feed. These measurements were repeated three times under the same experimental conditions. The permeate flux and acid retention were calculated by Equations (1) and (2), respectively.

$$
\begin{gathered}
J=\frac{V}{A \Delta t} \\
R_{\text {acid }}(\%)=\left(1-\frac{C_{p}}{C_{\mathrm{f}}}\right) \times 100
\end{gathered}
$$

where $\mathrm{J}$ is the permeate flux $\left(\mathrm{L} \cdot \mathrm{m}^{-2} \cdot \mathrm{h}^{-1}\right), \mathrm{V}$ is the permeate volume $(\mathrm{L}), \mathrm{A}$ is the effective membrane area $\left(\mathrm{m}^{2}\right)$, and $\Delta t$ is the measuring time (h). $R_{\text {acid }}$ is the acid retention and $C_{p}$ and $C_{f}$ are the acid concentrations of the permeate and feed $\left(\mathrm{g} \cdot \mathrm{L}^{-1}\right)$, respectively.

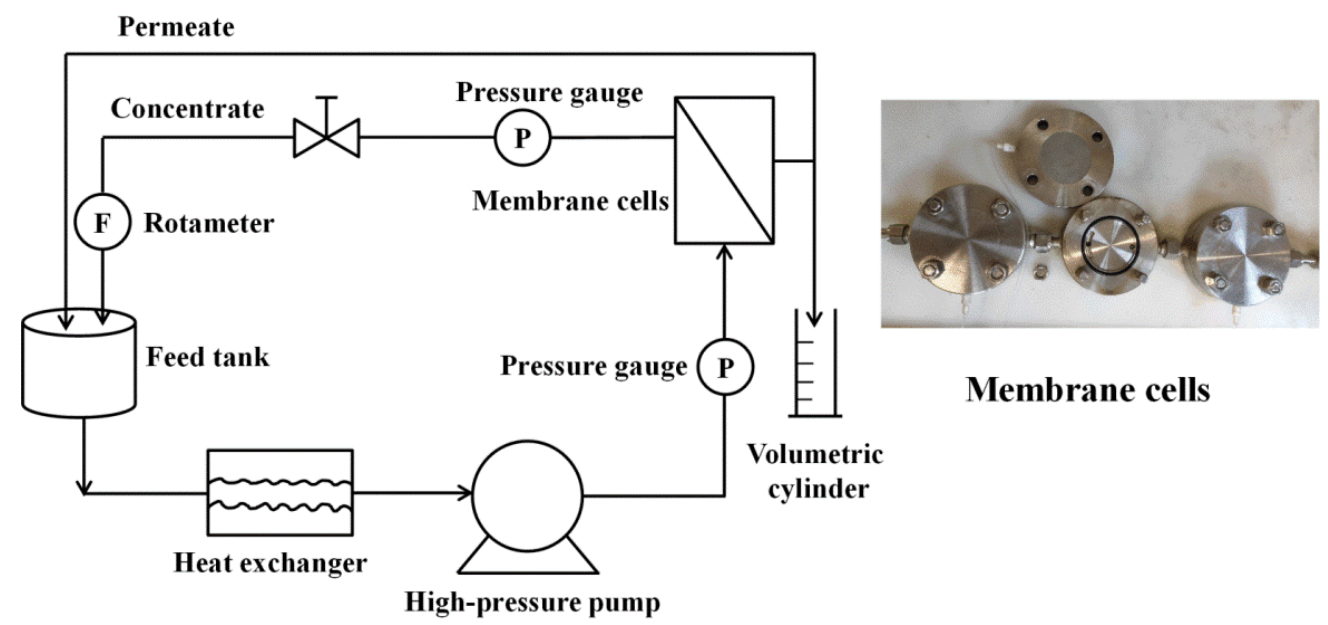

Figure 1. The schematic diagram of the cross-flow RO filtration apparatus. 


\subsection{Immersion Experiment}

To investigate the effects of continuous exposure to the acid solutions on the membrane characteristics, the two RO membranes (C5 and C6) were immersed in the acid solutions (Table 2) for 6 months at room temperature. At two months intervals, the membrane samples were taken and washed with deionized (DI) water. Subsequently, they were used for acid filtration experiments (Section 2.2), and their morphological and chemical characteristics were also tested (Section 2.4).

Table 2. Nomenclature and the acid solutions used for immersing the RO membranes.

\begin{tabular}{ccc}
\hline Sample & Membrane & Solution Concentration \\
\hline C5-Virgin $^{\mathrm{a}}$ & C5 & - \\
C5-2.5 & C5 & $2.5 \% \mathrm{AA}+2.5 \% \mathrm{HAc}$ \\
C5-7.5 & C5 & $7.5 \% \mathrm{AA}+7.5 \% \mathrm{HAc}$ \\
C6-Virgin ${ }^{\mathrm{b}}$ & $\mathrm{C} 6$ & - \\
C6-2.5 & C6 & $2.5 \% \mathrm{AA}+2.5 \% \mathrm{HAc}$ \\
C6-7.5 & C6 & $7.5 \% \mathrm{AA}+7.5 \% \mathrm{HAc}$ \\
\hline
\end{tabular}

a Sample C5-Virgin represented that samples C5-2.5 and C5-7.5 were immersed in the acid solutions for 0 months.

b Sample C6-Virgin represented that samples C6-2.5 and C6-7.5 were immersed in the acid solutions for 0 months.

\subsection{Analytical Methods}

The $\mathrm{pH}$ value of the solution was tested by a pH-meter (FE28-Standard, METTLER TOLEDO, Switzerland). The concentrations of acrylic acid and acetic acid were measured by Gas chromatography (GC, SP-2100A, Beifen, Beijing, China) with a FID detector and a capillary column (KB-FFAP, $30 \mathrm{~m} \times 0.32 \mathrm{~mm} \times 0.5 \mu \mathrm{m})$ using ethanol as an internal standard [24,25]. The temperatures of the injector, detector, and column were $200{ }^{\circ} \mathrm{C}, 220^{\circ} \mathrm{C}$, and $150{ }^{\circ} \mathrm{C}$, respectively. The flow rates of $\mathrm{N}_{2}$, air and $\mathrm{H}_{2}$ were $20 \mathrm{~mL} / \mathrm{min}, 300 \mathrm{~mL} / \mathrm{min}$ and $30 \mathrm{~mL} / \mathrm{min}$, respectively.

The membrane surface morphology was analyzed by scanning electron microscopy (SEM, S4800, Hitachi, Tokyo, Japan). The roughness of the membrane surface was tested by atomic force microscopy (AFM, Dimension icon, Bruker, Karlsruhe, Germany) using tapping mode. The membrane surface chemical composition was characterized by Fourier transform infrared spectroscopy (FT-IR, 6700, Nicolet, Madison, WI, USA) and X-ray photoelectron spectroscopy (XPS, ESCALAB-250Xi, ThermoFisher, Waltham, MA, USA).

\section{Results and Discussion}

\subsection{The Concentration Performance of the RO Membranes}

\subsubsection{Effect of Pressure}

The effect of pressure on permeate flux and acid retention for $\mathrm{C} 5$ and $\mathrm{C} 6$ at $25^{\circ} \mathrm{C}$ was showed in Figure 2. The feed solution contained $2.5 \%$ acrylic acid and $1.5 \%$ acetic acid based on the concentration of a specific tray in the absorption tower of the acrylic acid production process. The $\mathrm{pH}$ value of the feed solution was 2.39 .

As shown in Figure 2a, the permeate fluxes of both membranes were linearly dependent on the pressure. When the pressure varied from 2.0 $\mathrm{MPa}$ to $4.0 \mathrm{MPa}$, the permeate fluxes were increased from $7.89 \mathrm{~L} \cdot \mathrm{m}^{-2} \cdot \mathrm{h}^{-1}$ to $19.69 \mathrm{~L} \cdot \mathrm{m}^{-2} \cdot \mathrm{h}^{-1}$ for $\mathrm{C} 5$, and $8.36 \mathrm{~L} \cdot \mathrm{m}^{-2} \cdot \mathrm{h}^{-1}$ to $21.12 \mathrm{~L} \cdot \mathrm{m}^{-2} \cdot \mathrm{h}^{-1}$ for $\mathrm{C6}$, respectively. Meanwhile, the retentions of acrylic acid (Figure $2 b$ ) were significantly increased from $67.40 \%$ to $81.92 \%$ for C5, and $66.73 \%$ to $81.32 \%$ for C6, respectively. The retentions of acetic acid were slightly lower than those of acrylic acid. The similar trend was also reported by Zhou et al. [20,26] during the separation acetic acid from monosaccharides by RO. This phenomenon was induced by solution-diffusion theory [27]. With the increase of pressure, the water flux increased faster than solute flux, so the solute retention was increased. In addition, the solution-diffusion model was 
used to calculate the water permeability and the transport coefficients of two acids [28], as shown in Supplementary Figures S1 and Figure S2. For the acid solution containing $2.5 \%$ acrylic acid and $1.5 \%$ acetic acid, the water permeability coefficients of C5 and C6 were $7.195 \mathrm{~L} \cdot \mathrm{m}^{-2} \cdot \mathrm{h}^{-1} \cdot \mathrm{MPa}^{-1}$ and $7.694 \mathrm{~L} \cdot \mathrm{m}^{-2} \cdot \mathrm{h}^{-1} \cdot \mathrm{MPa}^{-1}$, respectively. The transport coefficients of acetic acid and acrylic acid were $4.275 \mathrm{~L} \cdot \mathrm{m}^{-2} \cdot \mathrm{h}^{-1}$ and $3.921 \mathrm{~L} \cdot \mathrm{m}^{-2} \cdot \mathrm{h}^{-1}$ for $\mathrm{C} 5$, and $4.669 \mathrm{~L} \cdot \mathrm{m}^{-2} \cdot \mathrm{h}^{-1}$ and $4.272 \mathrm{~L} \cdot \mathrm{m}^{-2} \cdot \mathrm{h}^{-1}$ for C6, respectively.

(a)

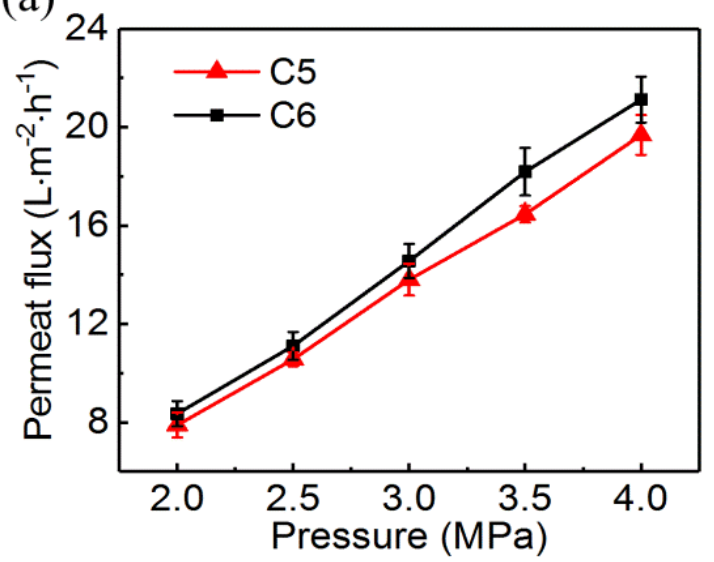

(b)

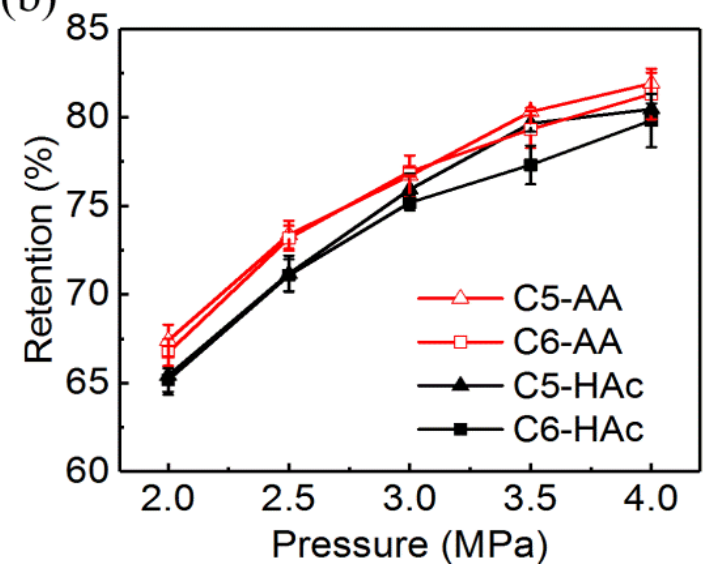

Figure 2. Effect of pressure on (a) permeate flux and (b) acrylic acid and acetic acid retentions. The concentrations of acrylic acid and acetic acid were $2.5 \%, 1.5 \%$, respectively; temperature: $25^{\circ} \mathrm{C}$.

As shown in Figure 2b, the retentions of acrylic acid and acetic acid were significantly lower than that of $\mathrm{NaCl}$ (Table 1). The similar results were also reported in the previous study $[20,27,29,30]$, as shown in Supplementary Table S1. The lower acid retention may be attributed to the following two factors. According to the surface absorption theory, the surface tension of the solution containing acrylic acid and acetic acid was lower than that of $\mathrm{NaCl}$ solution [31,32], which would cause more acid absorption by the membrane. On the other hand, the hydrogen bonding between the acid (AA and HAc) and the PA membrane would also increase the acid absorption [33]. $\mathrm{NaCl}$ was a strong electrolyte and existed as $\mathrm{Na}^{+}$and $\mathrm{Cl}^{-}$in the solution. The electrostatic repulsion between the PA membrane and the charged ions would increase the retention of $\mathrm{NaCl}$ [34]. Thus, $\mathrm{NaCl}$ could be better retained than acetic acid and acrylic acid by the membrane. The difference in hydrophilicity may be one of the reasons for the different retention of the two acids. The hydrophilicity of a compound was often described by the octanol/water partitioning coefficient $\left(\log \left(\mathrm{K}_{\mathrm{ow}}\right)\right)$, where a lower $\log \left(\mathrm{K}_{\mathrm{ow}}\right)$ was corresponding to a more hydrophilic compound [35,36]. So, the acetic acid $\left(\log \left(K_{o w}\right)=-0.17\right)$ [37] with a $\operatorname{lower} \log \left(\mathrm{K}_{\mathrm{ow}}\right)$ was more permeable than acrylic acid $\left(\log \left(\mathrm{K}_{\mathrm{ow}}\right)=0.36\right)$ at the same condition [35].

\subsubsection{Effect of Temperature}

The effect of temperature on permeate flux and acid retention was investigated from $20^{\circ} \mathrm{C}$ to $35^{\circ} \mathrm{C}$ at 3.5 MPa for $\mathrm{C} 5$ and $\mathrm{C} 6$. The feed concentrations of acrylic acid and acetic acid were $2.5 \%$ and $1.5 \%$, respectively. The permeate flux (Figure 3a) was increased almost linearly as temperature increased. However, the retentions of acrylic acid and acetic acid (Figure $3 b$ ) were significantly declined. As the temperature increased from $20^{\circ} \mathrm{C}$ to $35^{\circ} \mathrm{C}$, the retentions of acrylic acid and acetic acid (Figure 3a) were decreased by $9.6 \%$ and $9.5 \%$ for $\mathrm{C} 5$, and $12.4 \%$ and $11.5 \%$ for $\mathrm{C} 6$, respectively. 
(a)

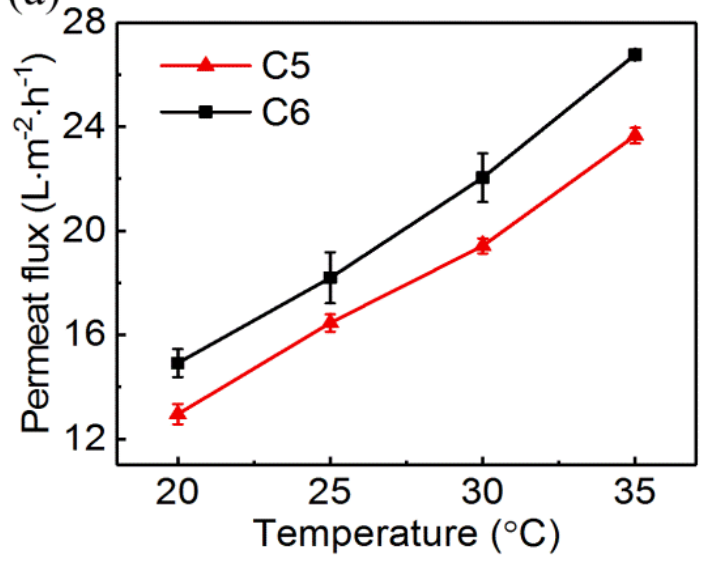

(b)

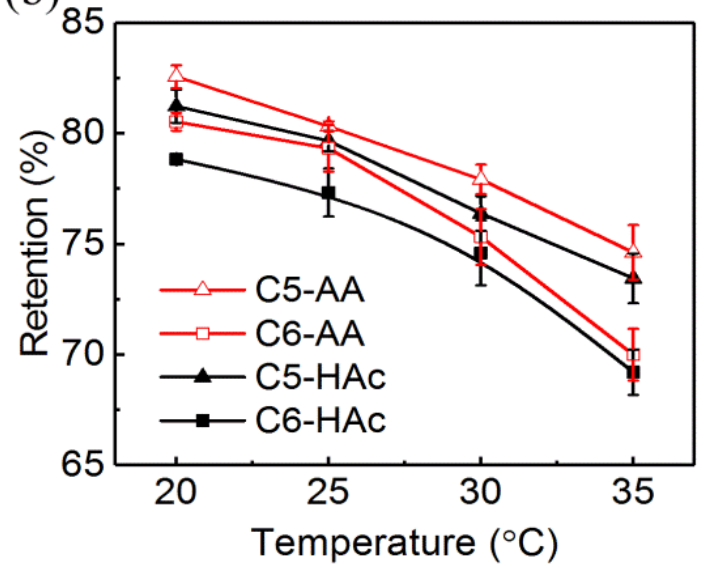

Figure 3. Effect of temperature on (a) permeate flux and (b) acrylic acid and acetic acid retentions. The concentrations of acrylic acid and acetic acid were $2.5 \%, 1.5 \%$, respectively; pressure: $3.5 \mathrm{MPa}$.

According to the Arrhenius relation, increasing temperature would promote the transport of water and solute through the membrane due to the increase of diffusion coefficient [38]. Moreover, it was reported that the increase in the mass transfer of solute was more significant than that of water with the increase of temperature [39], which would increase the permeate flux and reduce acid retention. The decrease of acid retention may be also attributed to the increase in membrane pore size caused by the thermal dilation of the polymer in the active layer at higher temperature $[38,40]$.

In the absorption process of acrylic acid production, the temperatures in the top and bottom of the absorption tower are about $43{ }^{\circ} \mathrm{C}$ and $70{ }^{\circ} \mathrm{C}$, respectively. The temperature of the solution taken from the absorption tower was about $45^{\circ} \mathrm{C}$. According to the operation conditions of the membrane recommended by the manufacturer, the maximum operating temperature of the two $\mathrm{RO}$ membranes is $45^{\circ} \mathrm{C}$. Therefore, the solution taken from the absorption tower was required to cool down before entering into the $\mathrm{RO}$ unit.

\subsubsection{Effect of Feed Concentration}

The effect of feed concentration on the RO membrane performance was assessed at $3.5 \mathrm{MPa}, 25{ }^{\circ} \mathrm{C}$ with two groups of acid solutions. In group A, the concentration of acrylic acid was 1.5\%, 2\%, 2.5\%, and $3 \%$, respectively, with the $1.5 \%$ acetic acid. In group $B$, the concentration of acetic acid was $1 \%$, $1.5 \%, 2 \%$, and $2.5 \%$, respectively, with the $2.5 \%$ acrylic acid.

Figure $4 a, c$ showed that the permeate fluxes of the two membranes were gradually decreased with the increase of the concentration of acrylic acid or acetic acid. The decrease in permeate flux was mainly due to the reduction in effective pressure caused by the increase of osmosis pressure [14,41]. There was no discernable difference in the retentions of acrylic acid and acetic acid in both the two membranes (Figure 4b,d). The similar results were also reported by other researchers [20,29]. For both the two membranes, the retentions of acrylic acid and acetic acid were about $80 \%$ and $78 \%$, respectively. 
(a)

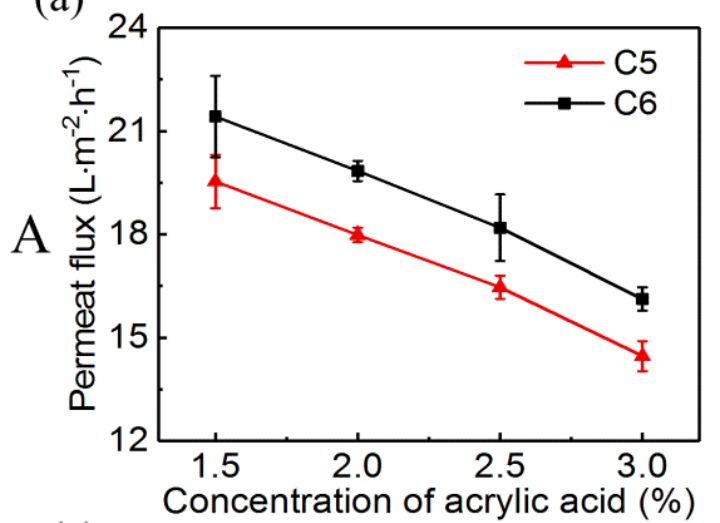

(c)

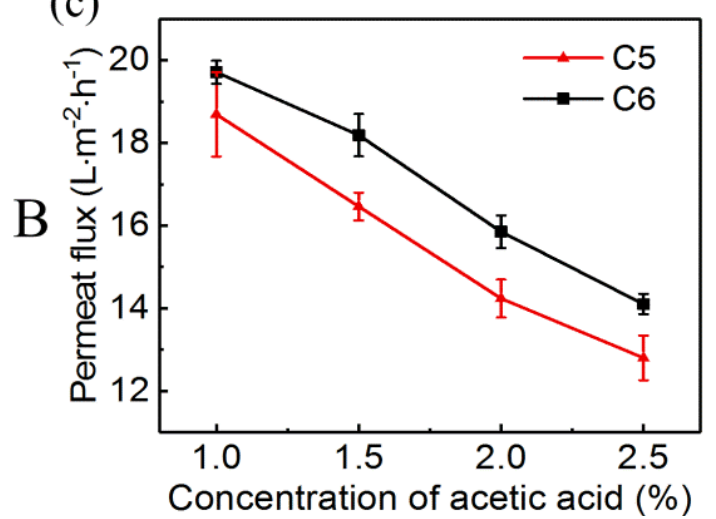

(b)



(d)



Figure 4. Effect of the feed concentration of acrylic acid (group A) on (a) permeate flux and (b) acrylic acid and acetic acid retentions, and the feed concentration of acetic acid (group B) on (c) permeate flux and (d) acrylic acid and acetic acid retentions. Pressure: $3.5 \mathrm{MPa}$; temperature: $25^{\circ} \mathrm{C}$.

\subsection{Effect of Continuous Exposure to the Acid Solutions on the Performance and Characteristics of} RO Membranes

\subsubsection{Permeate Flux and Acid Retention}

After immersed in the acidic solutions for several months, the permeate flux and acid retention of the $\mathrm{RO}$ membranes were tested to evaluate their acid resistance. The filtration experiments were performed at $3.5 \mathrm{MPa}$ and $25^{\circ} \mathrm{C}$ with an acid solution containing $2.5 \%$ acrylic acid and $1.5 \%$ acetic acid.

As shown in Figure 5, the permeate flux was increased, and the acid retention was decreased with the increase of the exposure time for all samples. The influences were more evident with the higher concentration of acid solution. The permeate fluxes of the samples C5-2.5 and C6-2.5 were increased by $33.1 \%$ and $15.3 \%$ after six months, respectively. The acrylic acid retentions of those were decreased by $5.7 \%$ and $4.9 \%$, respectively. Moreover, the acetic acid retentions of the two samples were decreased by $4.1 \%$ and $2.2 \%$, respectively. At the end of six months of exposure, the performance of samples C5-7.5 and C6-7.5 was degraded significantly. Compared with the virgin membranes, the retentions of acrylic acid and acetic acid were decreased by $14.4 \%$ and $9.6 \%$ for sample C5-7.5, and $11.7 \%$ and $6.4 \%$ for sample C6-7.5, respectively. 
(a)

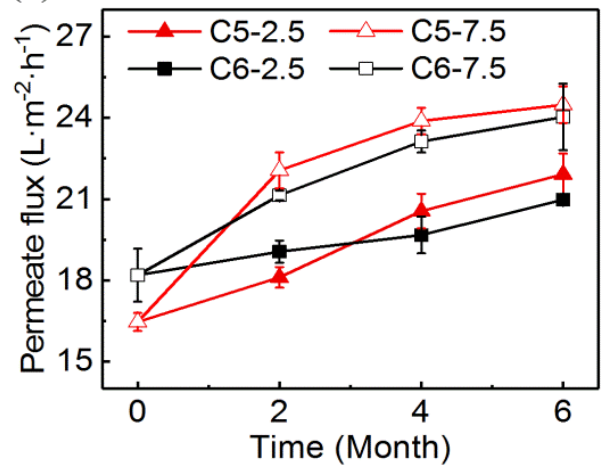

(b)

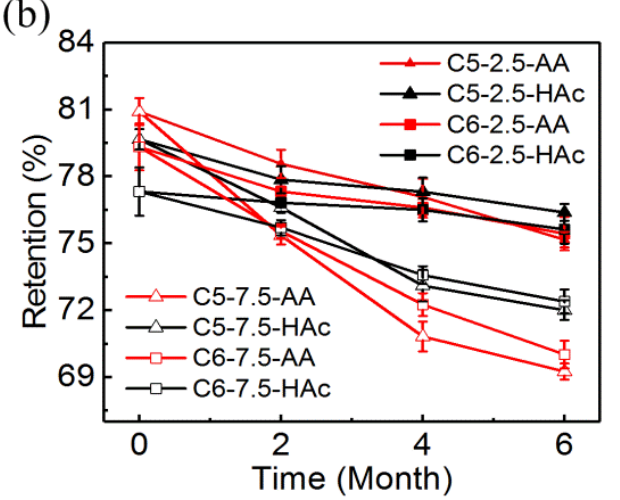

Figure 5. Effects of continuous exposure to the acid solutions on the (a) permeate flux and (b) acrylic acid and acetic acid retentions. The feed solution contained $2.5 \%$ acrylic acid and $1.5 \%$ acetic acid; temperature: $25^{\circ} \mathrm{C}$; pressure: $3.5 \mathrm{MPa}$.

\subsubsection{Membrane Surface Morphology}

The surface morphology of C5-2.5, C5-7.5, C6-2.5 and C6-7.5 before and after being immersed for six months was investigated by SEM. As shown in Figure 6, all samples exhibited a typical ridge-and-valley structure of the PA membrane. There was no apparent difference between the ridge structures of treated samples C5-2.5 and C6-2.5 and the untreated ones (samples C5-Virgin and C6-Virgin). The ridge structures of samples C5-7.5 and C6-7.5 spread out gradually attributed to the membranes swelling in the acid solutions [42]. In addition, as the acid concentration increased, the amount of ridge structures became less, and the area of each ridge structure became larger.
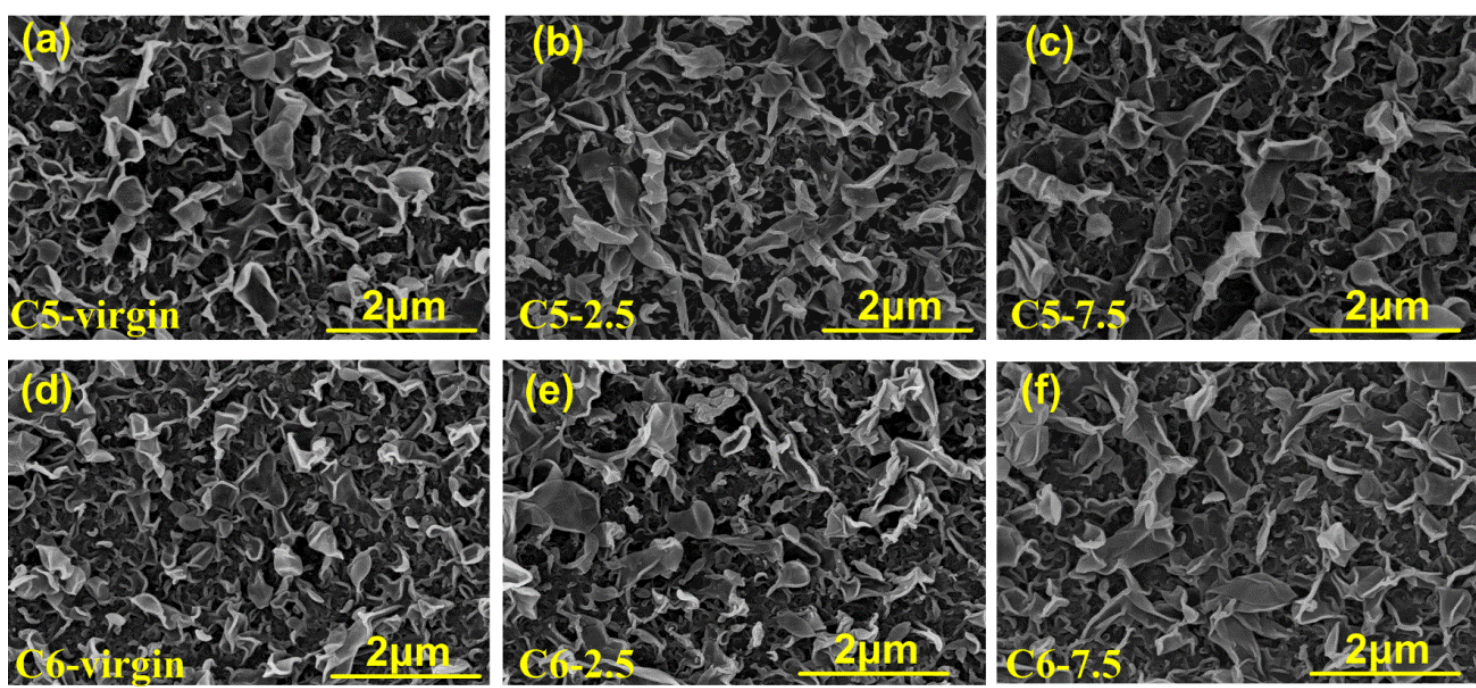

Figure 6. Surface SEM images of RO membranes: $(\mathbf{a}, \mathbf{d})$ prior to exposure and $(\mathbf{b}, \mathbf{c}, \mathbf{e}, \mathbf{f})$ after 6 months of exposure to the acid solutions.

The roughness of samples C5-2.5, C5-7.5, C6-2.5 and C6-7.5 after exposure for 0, 4, 6 months was tested by AFM, as shown in Table 3. The AFM images of the RO membranes were presented in Supplementary Figure S3. It was observed that the average roughness of all samples was decreased gradually with the exposure time increasing. For example, at the end of six months, the roughness of samples C5-7.5 and C6-7.5 was decreased by $24.8 \%$ and $12.6 \%$, respectively. The results indicated that the membrane surface became smoother, which was in accordance with the SEM micrographs. 
Table 3. The roughness of RO membranes before and after exposure to the acid solutions.

\begin{tabular}{cccc}
\hline \multirow{2}{*}{ Sample } & \multicolumn{3}{c}{ Average Roughness (nm) } \\
\cline { 2 - 4 } & 0 Month & 4 Months & 6 Months \\
\hline C5-2.5 & 137 & 127.5 & 117.0 \\
C5-7.5 & 137 & 108.6 & 103 \\
C6-2.5 & 87.2 & 86 & 78.9 \\
C6-7.5 & 87.2 & 83 & 76.2 \\
\hline
\end{tabular}

\subsubsection{Membrane Surface Chemical Composition}

The effect of continuous exposure to the acid solutions on membrane surface chemical composition was characterized by FT-IR and XPS. The FT-IR spectra detected in the range of $800-3500 \mathrm{~cm}^{-1}$ were shown in Figure 7, which contained both the bands of the active layer (PA) and the support layer (polysulfone, PSU) [43]. Two additional peaks were observed at $3300 \mathrm{~cm}^{-1}\left(\mathrm{NH}^{+}\right.$and $\mathrm{OH}^{-}$ groups) [44] and $1723 \mathrm{~cm}^{-1}$ (C=O of carboxylic acid) [45] for the samples C5-2.5 and C6-2.5 after exposure for six months, which may be attributed to the following two factors. Firstly, the oxygen was more electronegative than carbon. Therefore, the electro cloud of oxygen was higher than that of carbon in the acid solutions [46]. The carbon was more vulnerable to nucleophilic attack when the $\mathrm{H}^{+}$ attacked the amide bond, leading to the hydrolysis of the amide bond to the- $\mathrm{NH}_{2}$ and $-\mathrm{COOH}$ [47]. Secondly, the acrylic acid and acetic acid in the acid solutions were easy to be absorbed onto the RO membranes, which also could result in the appearance of the peak at $1723 \mathrm{~cm}^{-1}$. However, no significant disappearance of the peak was observed after six months of exposure to the acid solutions.

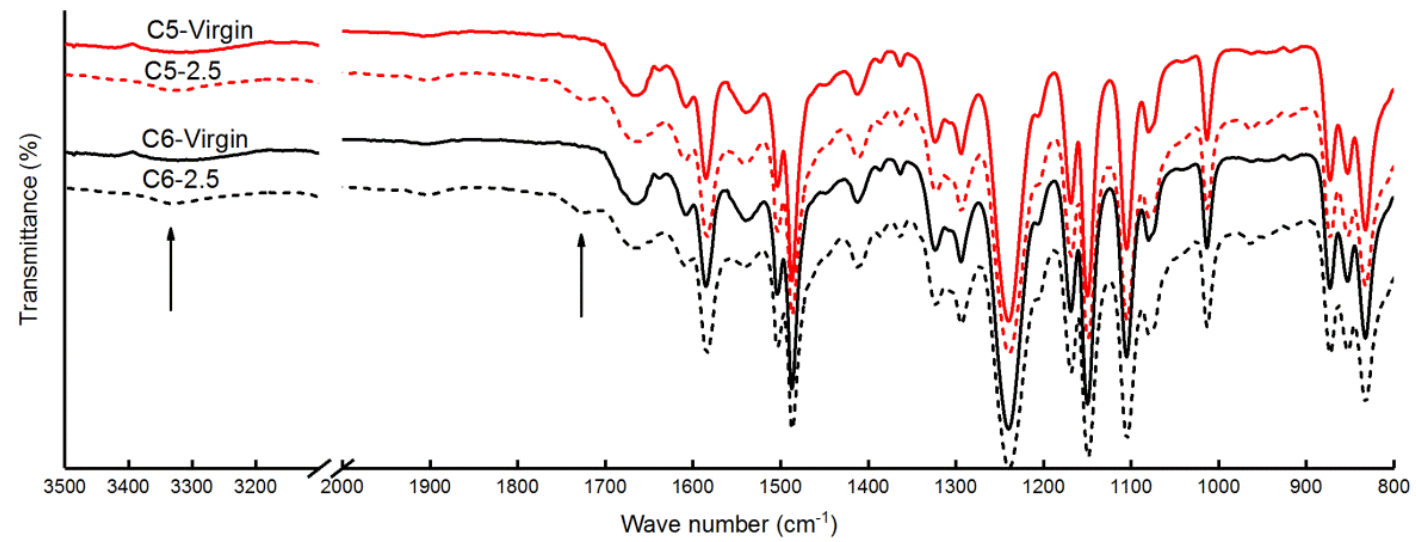

Figure 7. The FT-IR spectra of RO membranes before and after 6 months of exposure to the acid solutions containing $2.5 \%$ acrylic acid and $2.5 \%$ acetic acid.

The surface chemical composition of samples C5-2.5, C5-7.5, C6-2.5 and C6-7.5 prior and after 6 months to exposure was also detected by XPS. The atomic percent of C1s (284.8 eV), O1s (531.3 eV), $\mathrm{N} 1 \mathrm{~s}(399.8 \mathrm{eV})$ and the atomic ratio of $\mathrm{C} / \mathrm{O}, \mathrm{O} / \mathrm{N}$ were shown in Table 4 . The atomic percent of carbon and oxygen was increased which of nitrogen was decreased attributed to the absorption of acrylic acid and acetic acid and the hydrolysis of the amide bond [44]. The atomic ratio of $\mathrm{C} / \mathrm{O}$ was reduced and that of $\mathrm{O} / \mathrm{N}$ was increased. The atomic ratio of $\mathrm{O} / \mathrm{N}$ was 2 for the fully linear $\mathrm{PA}$, while $\mathrm{O} / \mathrm{N}$ was 1 for the fully cross-linked PA [43]. The increase of $\mathrm{O} / \mathrm{N}$ suggested that there were more additional oxygen atoms without being bonded to nitrogen atoms. Consistent with the FT-IR results, the lower atomic ratio of $\mathrm{C} / \mathrm{O}$ and the higher atomic ratio of $\mathrm{O} / \mathrm{N}$ indicated more free carboxylic groups due to the hydrolysis of the amide bond [44]. 
Table 4. The surface elemental composition of the RO membranes prior and after 6 months to exposure to the acid solutions by XPS.

\begin{tabular}{ccccccc}
\hline \multirow{2}{*}{ Sample } & \multirow{2}{*}{$\begin{array}{c}\text { Time } \\
\text { (Months) }\end{array}$} & \multicolumn{3}{c}{ Atomic Percent (at. \%) } & \multicolumn{2}{c}{ Atomic Ratio } \\
\cline { 3 - 7 } & & $\mathbf{N}$ & $\mathbf{C}$ & $\mathbf{O}$ & $\mathbf{C} / \mathbf{O}$ & O/N \\
\hline C5-Virgin & 0 & 12.08 & 74.54 & 13.36 & 6.17 & 1.11 \\
C5-2.5 & 6 & 10.27 & 75.43 & 14.30 & 5.27 & 1.39 \\
C5-7.5 & 6 & 10.10 & 75.57 & 14.33 & 5.27 & 1.41 \\
C6-Virgin & 0 & 11.11 & 76.82 & 12.06 & 6.37 & 1.09 \\
C6-2.5 & 6 & 10.76 & 76.26 & 12.99 & 5.87 & 1.21 \\
C6-7.5 & 6 & 9.62 & 76.34 & 14.04 & 5.44 & 1.46 \\
\hline
\end{tabular}

Furthermore, the narrow scans of carbon and nitrogen were detected, as shown in Table 5. The corresponding C1s spectra and N1s spectra of the membranes before and after exposure were presented in Supplementary Figures S4 and S5. There were four peaks of $\mathrm{C} 1 \mathrm{~s}$ in the results of all samples, which were observed at $284.3 \mathrm{eV}(\mathrm{C}-\mathrm{C}, \mathrm{C}-\mathrm{H}), 285.1 \mathrm{eV}(\mathrm{C}-\mathrm{O}, \mathrm{C}-\mathrm{N}), 287.7 \mathrm{eV}(\mathrm{C}=\mathrm{O}, \mathrm{O}=\mathrm{C}-\mathrm{N})$, and $290.4 \mathrm{eV}$ ( $\pi-\pi$ bonds) [44,48]. For nitrogen, the peak at $399.8 \mathrm{eV}$ represented $\mathrm{C}-\mathrm{N}$ and $\mathrm{O}=\mathrm{C}-\mathrm{N}$ [49]. Compared to the virgin membranes (samples C5-Virgin and C6-Virgin), an additional peak of the membranes exposed to acid solutions (samples C5-2.5, C5-7.5, C6-2.5 and C6-7.5) appeared in N1s scanning at $401.4 \mathrm{eV}\left(-\mathrm{NH}_{3}{ }^{+},-\mathrm{NH}_{2} \mathrm{R}^{+}\right)$. The component at $401.4 \mathrm{eV}$ was increased with the increase of the acid solution concentration. It was indicated that a higher concentration of acidic solution could result in more severe degradation of the membranes. The results also verified the hydrolysis of the amide bond caused by acrylic acid and acetic acid.

Table 5. The narrow scans of carbon (C1s) and nitrogen (N1s) of the RO membranes prior and after 6 months to exposure to the acid solutions by XPS.

\begin{tabular}{cccccccc}
\hline \multirow{2}{*}{ Sample } & \multirow{2}{*}{$\begin{array}{c}\text { Time } \\
\text { (Months) }\end{array}$} & \multicolumn{4}{c}{ C 1s } & \multicolumn{2}{c}{ N 1s } \\
\cline { 3 - 8 } & $\mathbf{2 8 4 . 3} \mathbf{~ e V}$ & $\mathbf{2 8 5 . 1} \mathbf{~ e V}$ & $\mathbf{2 8 7 . 7} \mathbf{~ e V}$ & $\mathbf{2 9 0 . 4} \mathbf{~ e V}$ & $\mathbf{3 9 9 . 8} \mathbf{~ e V}$ & $\mathbf{4 0 1 . 4 ~ \mathbf { ~ V }}$ \\
\hline C5-Virgin & 0 & 47.87 & 34.95 & 10.88 & 6.3 & 100 & - \\
C5-2.5 & 6 & 49.14 & 33.44 & 11.23 & 6.18 & 99.04 & 0.96 \\
C5-7.5 & 6 & 49.08 & 30.83 & 11.89 & 8.21 & 96.77 & 3.23 \\
C6-Virgin & 0 & 44.41 & 39.24 & 10.19 & 6.17 & 100 & - \\
C6-2.5 & 6 & 48.19 & 32.7 & 11.43 & 7.67 & 98.94 & 1.06 \\
C6-7.5 & 6 & 50.19 & 29.55 & 11.92 & 8.35 & 97.64 & 2.36 \\
\hline
\end{tabular}

\section{Conclusions}

In this work, two RO membranes were used to concentrate the solution containing acrylic acid and acetic acid under different operational conditions. With the pressure of $4 \mathrm{MPa}$ and the temperature of $25^{\circ} \mathrm{C}$, the permeate fluxes of SWC5 and SWC6 were $19.69 \mathrm{~L} \cdot \mathrm{m}^{-2} \cdot \mathrm{h}^{-1}$ and $21.12 \mathrm{~L} \cdot \mathrm{m}^{-2} \cdot \mathrm{h}^{-1}$, respectively. For both membranes, the retentions of acrylic acid and acetic acid were around $80 \%$ and $78 \%$, respectively. The stability of the membranes in the acid solutions was also assessed. The longer exposure time and the higher acid concentration would decline the membrane performance. After six months of exposure to the acid solution containing $2.5 \%$ acrylic acid and $2.5 \%$ acetic acid, the acrylic acid retentions of SWC5 and SWC6 were decreased by $5.7 \%$ and $4.9 \%$, and the acetic acid retentions of those were decreased by $4.1 \%$ and $2.2 \%$, respectively. With the acid solution containing $7.5 \%$ acrylic acid and $7.5 \%$ acetic acid, the retentions of acrylic acid and acetic acid were decreased by $14.4 \%$ and $9.6 \%$ for SWC5, and $11.7 \%$ and $6.4 \%$ for SWC6, respectively. The increase of membrane surface roughness and the hydrolysis of some amide bonds were consistent with the changes of membrane performance. The results showed that it is possible to concentrate a lower concentration side stream of the absorption tower by RO. 
Supplementary Materials: The following are available online at http://www.mdpi.com/2077-0375/10/7/142/s1, Figure S1: Determination of the water permeability of the membranes for the acid solution, Figure S2: Determination of the acid transport coefficients of the C5 (a) and C6 (b) by fitting the acid retention and water flux at different pressures, Figure S3: AFM images of RO membranes: $(\mathrm{a}, \mathrm{d})$ prior to exposure and $(\mathrm{b}, \mathrm{c}, \mathrm{e}, \mathrm{f})$ after 6 months of exposure to the acid solutions, Figure S4: The C1s spectra and N1s spectra of C5 membranes: $(a, b)$ prior to exposure and (c-f) after 6 months of exposure to the acid solutions, Figure S5: The C1s spectra and N1s spectra of C6 membranes: $(a, b)$ prior to exposure and $(c-f)$ after 6 months of exposure to the acid solutions, Table S1: Comparison of the acetic retention with those in the literature.

Author Contributions: Conceptualization, L.X., Q.L., H.D., and Y.D.; methodology, Q.L., H.D., and S.X.; investigation, Q.L. and H.D.; data curation, Q.L. and H.D.; writing-original draft preparation, Q.L. and H.D.; writing-review and editing, Q.L., H.D., L.X., S.X., and Y.D.; funding acquisition, L.X. and Y.D.; All authors have read and agreed to the published version of the manuscript.

Funding: This research was funded by the National Key R\&D Program of China, grant number 2016 YFC0401202. This research was also funded by the National Natural Science Foundation of China (No. 21606067), and the Hebei Province Natural Science Foundation of China (B2018202120).

Conflicts of Interest: The authors declare no conflict of interest.

\section{References}

1. Beerthuis, R.; Rothenberg, G.; Shiju, N.R. Catalytic routes towards acrylic acid, adipic acid and $\varepsilon$-caprolactam starting from biorenewables. Green Chem. 2015, 17, 1341-1361. [CrossRef]

2. Sun, D.; Yamada, Y.; Sato, S.; Ueda, W. Glycerol as a potential renewable raw material for acrylic acid production. Green Chem. 2017, 19, 3186-3213. [CrossRef]

3. Grasselli, R.K.; Trifirò, F. Acrolein and acrylic acid from biomass. Rend. Lincei-Sci. Fis. 2017, 28, 59-67. [CrossRef]

4. Straathof, A.J.; Sie, S.; Franco, T.T.; van der Wielen, L.A. Feasibility of acrylic acid production by fermentation. Appl. Microbiol. Biotechnol. 2005, 67, 727-734. [CrossRef] [PubMed]

5. Kim, M.; Lee, H. Highly selective production of acrylic acid from glycerol via two steps using $\mathrm{Au} / \mathrm{CeO} 2$ catalysts. ACS Sustain. Chem. Eng. 2017, 5, 11371-11376. [CrossRef]

6. Wang, W.; Wang, Y. Processes of producing acrylic acid by two-step process of propylene. Chem. Eng. Des. Commun. 2018, 44, 122-214.

7. Li, A.; Dong, N.; He, M.; Pan, T. Evaluation of performance in a combined UASB and aerobic contact oxidation process treating acrylic wastewater. Environ. Technol. 2015, 36, 807-814. [CrossRef]

8. Briegel, K.F.; Stanley, D.M.; James, E.; Jerrick, J.J.; Lydon, M.J. Method for Production of Aqueous (Meth)acrylic Acid. U.S. Patent 2009299095 A1, 25 October 2011.

9. Min, Y.J.; Baek, S.W.; Song, J.H.; Kim, J.Y. Method of Continuous Recovery of (Meth)acrylic Acid and Apparatus for the Method. U.S. Patent 20190071383 A1, 3 July 2019.

10. Aghapour Aktij, S.; Zirehpour, A.; Mollahosseini, A.; Taherzadeh, M.J.; Tiraferri, A.; Rahimpour, A. Feasibility of membrane processes for the recovery and purification of bio-based volatile fatty acids: A comprehensive review. J. Ind. Eng. Chem. 2020, 81, 24-40. [CrossRef]

11. Lyu, H.; Chen, K.; Yang, X.; Younas, R.; Zhu, X.; Luo, G.; Zhang, S.; Chen, J. Two-stage nanofiltration process for high-value chemical production from hydrolysates of lignocellulosic biomass through hydrothermal liquefaction. Sep. Purif. Technol. 2015, 147, 276-283. [CrossRef]

12. Baruah, K.; Hazarika, S. Separation of acetic acid from dilute aqueous solution by nanofiltration membrane. J. Appl. Polym. Sci. 2014, 131, 1-9. [CrossRef]

13. Lakra, R.; Saranya, R.; Lukka Thuyavan, Y.; Sugashini, S.; Begum, K.M.M.S.; Arthanareeswaran, G. Separation of acetic acid and reducing sugars from biomass derived hydrosylate using biopolymer blend polyethersulfone membrane. Sep. Purif. Technol. 2013, 118, 853-861. [CrossRef]

14. Ricci, B.C.; Ferreira, C.D.; Marques, L.S.; Martins, S.S.; Amaral, M.C.S. Assessment of nanofiltration and reverse osmosis potentialities to recover metals, sulfuric acid, and recycled water from acid gold mining effluent. Water Sci. Technol. 2016, 74, 367-374. [CrossRef] [PubMed]

15. Menchik, P.; Moraru, C.I. Nonthermal concentration of liquid foods by a combination of reverse osmosis and forward osmosis. Acid whey: A case study. J. Food Eng. 2019, 253, 40-48. [CrossRef]

16. Wang, F.; Hao, H.; Sun, R.; Li, S.; Han, R.; Papelis, C.; Zhang, Y. Bench-scale and pilot-scale evaluation of coagulation pre-treatment for wastewater reused by reverse osmosis in a petrochemical circulating cooling water system. Desalination 2014, 335, 64-69. [CrossRef] 
17. Belkacem, M.; Bensadok, K.; Refes, A.; Charvier, P.M.; Nezzal, G. Water produce for pharmaceutical industry: Role of reverse osmosis stage. Desalination 2008, 221, 298-302. [CrossRef]

18. González, M.P.; Navarro, R.; Saucedo, I.; Avila, M.; Revilla, J.; Bouchard, C. Purification of phosphoric acid solutions by reverse osmosis and nanofiltration. Desalination 2002, 147, 315-320. [CrossRef]

19. Ricci, B.C.; Ferreira, C.D.; Aguiar, A.O.; Amaral, M.C.S. Integration of nanofiltration and reverse osmosis for metal separation and sulfuric acid recovery from gold mining effluent. Sep. Purif. Technol. 2015, 154, 11-21. [CrossRef]

20. Zhou, F.; Wang, C.; Wei, J. Simultaneous acetic acid separation and monosaccharide concentration by reverse osmosis. Bioresour. Technol. 2013, 131, 349-356. [CrossRef]

21. Chen, C.; Ma, K.; Zhu, Q.; Tan, F.; Wang, Y.; He, M.; Hu, G. A method for concentration of monosaccharide and removal of inhibitors during hydrolysate pretreatment for improved bioethanol production. J. Clean. Prod. 2020, 260, 120999. [CrossRef]

22. Ahsan, L.; Jahan, M.S.; Ni, Y. Recovering/concentrating of hemicellulosic sugars and acetic acid by nanofiltration and reverse osmosis from prehydrolysis liquor of kraft based hardwood dissolving pulp process. Bioresour. Technol. 2014, 155, 111-115. [CrossRef]

23. Huifen, T.; Zhonghai, C.; Tao, L.; Ming, W. Study on the acid and alkali resistance of commercial seawater desalination RO membranes. Technol. Water Treat. 2016, 42, 70-74.

24. Wang, M.; Wang, J.; Choong, Y. Simultaneous quantification of methanol and ethanol in alcoholic beverage using a rapid gas chromatographic method coupling with dual internal standards. Food Chem. 2004, 86, 609-615. [CrossRef]

25. Esposito, G.G.; Schaefer, K.K. Gas chromatographic determination of acetic acid in industrial atmosphere and waste water. Am. Ind. Hyg. Assoc. J. 1976, 37, 268. [CrossRef] [PubMed]

26. Zhou, F.; Wang, C.; Wei, J. Separation of acetic acid from monosaccharides by NF and RO membranes: Performance comparison. J. Membr. Sci. 2013, 429, 243-251. [CrossRef]

27. Teella, A.; Huber, G.W.; Ford, D.M. Separation of acetic acid from the aqueous fraction of fast pyrolysis bio-oils using nanofiltration and reverse osmosis membranes. J. Membr. Sci. 2011, 378, 495-502. [CrossRef]

28. Abejón, R.; Garea, A.; Irabien, A. Ultrapurification of hydrogen peroxide solution from ionic metals impurities to semiconductor grade by reverse osmosis. Sep. Purif. Technol. 2010, 76, 44-51. [CrossRef]

29. Lyu, H.; Fang, Y.; Ren, S.; Chen, K.; Luo, G.; Zhang, S.; Chen, J. Monophenols separation from monosaccharides and acids by two-stage nanofiltration and reverse osmosis in hydrothermal liquefaction hydrolysates. J. Membr. Sci. 2016, 504, 141-152. [CrossRef]

30. Nguyen, N.; Fargues, C.; Guiga, W.; Lameloise, M.L. Assessing nanofiltration and reverse osmosis for the detoxification of lignocellulosic hydrolysates. J. Membr. Sci. 2015, 487, 40-50. [CrossRef]

31. Lvarez, E.A.; Zquez, G.V.; Nchez-Vilas, M.S.; Sanjurjo, B.A.; Navaza, J.M. Surface Tension of Organic Acids + Water Binary Mixtures from $20^{\circ} \mathrm{C}$ to $50^{\circ} \mathrm{C}$. J. Chem. Eng. Data 1997, 42, 957-960. [CrossRef]

32. Wang, X.; Chen, C.; Binder, K.; Kuhn, U.; Pöschl, U.; Su, H.; Cheng, Y. Molecular dynamics simulation of the surface tension of aqueous sodium chloride: From dilute to highly supersaturated solutions and molten salt. Atmos. Chem. Phys. 2018, 18, 17077-17086. [CrossRef]

33. Duvel, W.A., Jr.; Helfgott, T. Removal of Wastewater Organics by Reverse Osmosis. J. Water Pollut. Control Fed. 1975, 47, 57-65. [PubMed]

34. Takeuchi, K.; Takizawa, Y.; Kitazawa, H.; Fujii, M.; Hosaka, K.; Ortiz-Medina, J.; Morelos-Gomez, A.; Cruz-Silva, R.; Fujishige, M.; Akuzawa, N.; et al. Salt rejection behavior of carbon nanotube-polyamide nanocomposite reverse osmosis membranes in several salt solutions. Desalination 2018, 443, 165-171. [CrossRef]

35. Agenson, K. Retention of a wide variety of organic pollutants by different nanofiltration/reverse osmosis membranes: Controlling parameters of process. J. Membr. Sci. 2003, 225, 91-103. [CrossRef]

36. Breitner, L.N.; Howe, K.J.; Minakata, D. Effect of functional chemistry on the rejection of low-molecular weight neutral organics through reverse osmosis membranes for potable reuse. Environ. Sci. Technol. 2019, 53, 11401-11409. [CrossRef]

37. Bellona, C.; Drewes, J.E. The role of membrane surface charge and solute physico-chemical properties in the rejection of organic acids by NF membranes. J. Membr. Sci. 2005, 249, 227-234. [CrossRef] 
38. Sharma, R.R.; Agrawal, R.; Chellam, S. Temperature effects on sieving characteristics of thin-film composite nanofiltration membranes: Pore size distributions and transport parameters. J. Membr. Sci. 2003, 223, 69-87. [CrossRef]

39. Nilsson, M.; Trägårdh, G.; Östergren, K. The influence of $\mathrm{pH}$, salt and temperature on nanofiltration performance. J. Membr. Sci. 2008, 312, 97-106. [CrossRef]

40. Ben Amar, N.; Saidani, H.; Deratani, A.; Palmeri, J. Effect of temperature on the transport of water and neutral solutes across nanofiltration membranes. Langmuir 2007, 23, 2937-2952. [CrossRef]

41. Pino, L.; Vargas, C.; Schwarz, A.; Borquez, R. Influence of operating conditions on the removal of metals and sulfate from copper acid mine drainage by nanofiltration. Chem. Eng. J. 2018, 345, 114-125. [CrossRef]

42. Platt, S.; Nyström, M.; Bottino, A.; Capannelli, G. Stability of NF membranes under extreme acidic conditions. J. Membr. Sci. 2004, 239, 91-103. [CrossRef]

43. Tang, C.Y.; Kwon, Y.; Leckie, J.O. Effect of membrane chemistry and coating layer on physiochemical properties of thin film composite polyamide RO and NF membranes I. FTIR and XPS characterization of polyamide and coating layer chemistry. Desalination 2009, 242, 149-167. [CrossRef]

44. López, J.; Reig, M.; Gibert, O.; Torres, E.; Ayora, C.; Cortina, J.L. Application of nanofiltration for acidic waters containing rare earth elements: Influence of transition elements, acidity and membrane stability. Desalination 2018, 430, 33-44. [CrossRef]

45. Yun, T.; Chung, J.W.; Kwak, S. Recovery of sulfuric acid aqueous solution from copper-refining sulfuric acid wastewater using nanofiltration membrane process. J. Environ. Manag. 2018, 223, 652-657. [CrossRef] [PubMed]

46. Wei, X.; Xu, X.; Wu, J.; Li, C.; Chen, J.; Lv, B.; Zhu, B.; Xiang, H. SiO 2 -modified nanocomposite nanofiltration membranes with high flux and acid resistance. J. Appl. Polym. Sci. 2019, 136, 47436. [CrossRef]

47. Hoseinpour, H.; Peyravi, M.; Nozad, A.; Jahanshahi, M. Static and dynamic assessments of polysulfonamide and poly(amide-sulfonamide) acid-stable membranes. J. Taiwan Inst. Chem. Eng. 2016, 67, 453-466. [CrossRef]

48. Zhao, C.; Tang, C.Y.; Li, P.; Adrian, P.; Hu, G. Perfluorooctane sulfonate removal by nanofiltration membrane-the effect and interaction of magnesium ion/humic acid. J. Membr. Sci. 2016, 503, 31-41. [CrossRef]

49. Do, V.T.; Tang, C.Y.; Reinhard, M.; Leckie, J.O. Degradation of polyamide nanofiltration and reverse osmosis membranes by hypochlorite. Environ. Sci. Technol. 2011, 46, 852-859. [CrossRef] 